\title{
Heat Stress Elicits Different Responses in Peripheral Blood Mononuclear Cells from Brown Swiss and Holstein Cows ${ }^{1}$
}

\author{
N. Lacetera, ${ }^{2}$ U. Bernabucci, D. Scalia, L. Basiricò, P. Morera, and A. Nardone \\ Dipartimento di Produzioni Animali, Università degli Studi della Tuscia, Via San Camillo de Lellis, 01100 Viterbo, Italy
}

\begin{abstract}
This study was undertaken to assess whether peripheral blood mononuclear cells (PBMC) isolated from Brown Swiss (Br) and Holstein (Ho) cows and stimulated with concanavalin A differ in response to chronic exposure to incubation temperatures simulating conditions of hyperthermia. Five multiparous $\mathrm{Br}$ and $5 \mathrm{Ho}$ cows were utilized as blood donors. Peripheral blood mononuclear cells were subjected for $65 \mathrm{~h}$ to each of 5 treatments (T). Cells were exposed to $39^{\circ} \mathrm{C}$ continuously (T39) and three 13-h cycles at 40 (T40), 41 (T41), 42 (T42) or $43^{\circ} \mathrm{C}$ (T43), respectively, which were interspersed with two 13 -h cycles at $39^{\circ} \mathrm{C}$. Treatment T39 was adopted to mimic normothermia; T40, T41, T42, and T43 mimicked conditions of more severe hyperthermia alternating with normothermia. Measures evaluated at the end of the incubation period were proliferative response (DNA synthesis), intracellular reactive oxygen species (ROS) concentrations, and mRNA abundance of the 72-kDa heat-shock protein (Hsp72). In $\mathrm{Br}$ cows, DNA synthesis began to decline when PBMC were repeatedly exposed to $41^{\circ} \mathrm{C}(-22 \%)$, whereas DNA synthesis in cells isolated from Ho cows did not begin to decline until $42^{\circ} \mathrm{C}(-40 \%)$. Furthermore, under T41 and T42, DNA synthesis from $\mathrm{Br}$ cows was lower than in Ho (-24 and $-54 \%$, respectively). In both breeds, increased incubation temperatures caused a reduction of intracellular ROS (from -39.6 and -69.7\%). Increase in incubation temperatures enhanced Hsp72 mRNA levels only in PBMC isolated from $\mathrm{Br}$ cows. The Hsp72 mRNA in $\mathrm{Br}$ cows increased significantly under $\mathrm{T} 41$ and $\mathrm{T} 43$ compared with T39. In both breeds, DNA synthesis was positively and negatively correlated with intracellular ROS and Hsp72 mRNA abundance, respectively ( $\mathrm{r}=$ 0.85 and $r=-0.70$, respectively). Results indicated that PBMC from Br cows are less tolerant to chronic heat exposure than those from Ho cows, and that the lower tolerance is associated with higher expression of Hsp72,
\end{abstract}

\footnotetext{
Received June 2, 2006.

Accepted July 20, 2006.

${ }^{1}$ This study was financially co-supported by MIUR (PRIN 03) and Università degli Studi della Tuscia.

${ }^{2}$ Corresponding author: nicgio@unitus.it
}

suggesting that the same level of hyperthermia may be associated with a differential decline of immune function in the 2 breeds.

Key words: Brown Swiss, Holstein, temperature, peripheral blood mononuclear cell

\section{INTRODUCTION}

A series of in vitro studies demonstrated that exposure of bovine peripheral blood mononuclear cells (PBMC) to short and severe heat shock reduced responsiveness to mitogens or decreased the number of viable cells (Elvinger et al., 1991; Kamwanja et al., 1994).

Different researchers (Johnson, 1965; Correa-Calderon et al., 2004) indicated that Brown Swiss (Br) cows are less sensitive to hot environment exposure than Holstein (Ho) cows. These studies established heat sensitivity by measuring rectal temperature under hot environments and concluded that $\mathrm{Br}$ cows are more resistant to heat than Ho because their increase in body temperature under heat stress is less pronounced than that of Ho. To our knowledge, no in vivo or in vitro comparative studies have been conducted in breeds belonging to Bos taurus subspecies to establish whether different levels of hyperthermia are associated with a decline in functions of immune cells. A comparative in vitro study was performed to evaluate cellular tolerance to heat in Bos indicus vs. B. taurus breeds (Kamwanja et al., 1994); however, that study did clarify the mechanisms conferring higher tolerance to cells isolated from $B$. indicus breeds, and it was not designed to assess cell function or viability after a short-term exposure to heat-shock conditions.

Hyperthermia promotes oxidative stress in cells of laboratory animals, and that effect may be ascribed to different mechanisms, which include increased formation rate of reactive oxygen species (ROS; Flanagan et al., 1998). Furthermore, Pahlavani and Harris (1998) demonstrated that increased in vitro generation of oxygen free radicals due to hyperthermia was associated with inhibition of proliferation (DNA synthesis) and IL2 gene expression in $\mathrm{T}$ cells from rats.

Cellular response to heat shock includes synthesis of proteins belonging to a subgroup of molecular chaperones called heat-shock proteins (Hsp), and classified 
into 5 families according to their molecular weight (100, 90, 70, 60, and small Hsp; Kristensen et al., 2004). The protective role of Hsp is usually confined to their chaperone function; that is, their capacity to bind denatured proteins and thus prevent their irreversible aggregation (Lindquist, 1986). In the bovine, Hsp72 is absent or expressed at a low level under nonstress conditions and is referred to as the inducible form of the Hsp70 family (Welch, 1992; Kristensen et al., 2004).

This in vitro study was undertaken to assess whether PBMC isolated from $\mathrm{Br}$ and Ho cows and stimulated with concanavalin A (ConA) differ in response to chronic exposure to temperatures simulating conditions of hyperthermia. Measures taken into consideration at the end of the incubation period were DNA synthesis (a measure of the reactivity of lymphocytes; Tizard, 1992), intracellular ROS, and Hsp72 mRNA levels.

\section{MATERIALS AND METHODS}

\section{Cows and Samplings}

Five $\mathrm{Br}$ and 5 Ho healthy cows originated from a commercial dairy unit, were similar for stage of lactation and parity, and were under the same management and nutritional regimen at the time of samplings. Blood collections were conducted in early spring (April 2004), during a thermoneutral period with values of the temperature humidity index constantly below 72 , which is considered the upper critical value for dairy cows (Johnson, 1987). Blood samples (20 mL) were obtained 5 times over a 3 -wk period by jugular venipuncture using sodium heparin (10 IU/mL) as an anticoagulant. Immediately after collection, blood samples were stored in a portable refrigerator at $4^{\circ} \mathrm{C}$ and transferred to the laboratory.

\section{Laboratory Analysis}

PBMC Isolation. The PBMC were isolated by density gradient centrifugation (Lacetera et al., 2002). Briefly, blood was diluted, layered over Ficoll-Paque PLUS (APB, Milano, Italy), and centrifuged. The mononuclear cell band was recovered and washed twice in PBS (Sigma, Milano, Italy). Residual red blood cells were eliminated by hypotonic shock treatment using redistilled water. The PBMC recovery and viability were determined by hemocytometer count using the trypan blue exclusion method. Viability of PBMC typically exceeded $90 \%$ both in $\mathrm{Br}$ and Ho cows. The PBMC were resuspended at $1 \times 10^{6}$ viable cells $/ \mathrm{mL}$ in RPMI 1640 medium (Sigma) containing $25 \mathrm{~m} M$ HEPES (Sigma) supplemented with $10 \%$ heat-inactivated fetal bovine serum, $2 \mathrm{mM}$ L-glutamine, $100 \mathrm{U}$ of penicillin,
$100 \mu \mathrm{g}$ of streptomycin, and $0.25 \mu \mathrm{g}$ of amphotericin B/ $\mathrm{mL}$ (Sigma). The time between blood collections and establishment of cultures was less than $6 \mathrm{~h}$.

Treatments. The PBMC isolated from the 10 cows were subjected for $65 \mathrm{~h}$ to each of 5 treatments (T; Table 1). The 65-h incubation represents an optimal time to guarantee cell viability and elicit maximum proliferative response in bovine PBMC (Lacetera et al., 2005). Cells were exposed to $39^{\circ} \mathrm{C}$ continuously (T39) or three 13 -h cycles at $40(\mathbf{T 4 0}), 41(\mathbf{T 4 1}), 42(\mathbf{T 4 2})$, or $43^{\circ} \mathrm{C}$ (T43), respectively, which were interspersed with two 13 -h cycles at $39^{\circ} \mathrm{C}$. Treatment T39 was adopted to mimic normothermia; T40, T41, T42, and T43 mimicked conditions of more severe hyperthermia alternated with normothermia.

PBMC Cultures for Proliferation Assay. The PBMC $(100 \mu \mathrm{L})$ were added into triplicate wells of 96well, flat-bottomed tissue culture plates. The mitogen ConA (Sigma) was added at final concentration of 2.5 $\mu \mathrm{g} / \mathrm{mL}$. Control wells contained $100 \mu \mathrm{L}$ of PBMC suspension $\left(1 \times 10^{6}\right.$ viable cells $/ \mathrm{mL}$ ) without ConA (unstimulated). Additional control wells contained $100 \mu \mathrm{L}$ of complete RPMI 1640, or $100 \mu \mathrm{L}$ of PBMC suspension without 5-bromo-2'-deoxyuridine (BrdU, see below). Tissue culture plates were subjected to the treatment protocol in an atmosphere of $95 \%$ air and $5 \% \mathrm{CO}_{2}$. After the first $48 \mathrm{~h}$ of incubation, $10 \mu M$ of pyrimidine analogue BrdU (APB) in $10 \mu \mathrm{L}$ of RPMI 1640 was added to each well. Following a 17-h incubation, DNA synthesis was verified by ELISA using a commercial kit (Biotrak, APB) based on the measurements of BrdU incorporation during DNA synthesis in proliferating cells. Values for DNA synthesis were expressed as the optical density recorded at $450 \mathrm{~nm}$ wavelength, both in unstimulated and stimulated wells, minus the optical density recorded in control wells without BrdU.

PBMC Cultures for ROS and Hsp72 Quantification. Intracellular ROS and mRNA for Hsp72 were evaluated in PBMC ( $1 \mathrm{~mL}$ of cell suspension containing $1 \times 10^{6}$ cells/well) cultured under the conditions described above. The PBMC were cultured in duplicate in 24-well tissue-culture plates. At the end of the incubation period, cell suspensions were transferred into centrifuge tubes and centrifuged at $1,000 \times \mathrm{g}\left(\mathrm{g}_{\max }\right)$ for $15 \mathrm{~min}$, the supernatants were discarded, and the dry pellets (containing whole $\mathrm{PBMC}$ ) were stored at $-80^{\circ} \mathrm{C}$ until analyzed.

ROS Quantification. Dry pellets of PBMC were treated with $100 \mu \mathrm{L}$ of ice-cold lysis buffer prepared by adding $5 \mu \mathrm{L}$ of a $10 \%$ solution of Triton X-100 and 0.5 $\mu \mathrm{L}$ of $0.2 \mathrm{M}$ phenylmethylsulfonyl fluoride to $94.5 \mu \mathrm{L}$ of PBS. Lysis of PBMC was performed by keeping cells on ice; cells were lysed for $15 \mathrm{~min}$ and were occasionally stirred. Afterwards, the cell lysate was centrifuged at 
Table 1. Schematic representation of the experimental treatments ${ }^{1}$

\begin{tabular}{llllll}
\hline & \multicolumn{5}{c}{ Timing of cycle } \\
\cline { 2 - 5 } Treatment & 0 to $13 \mathrm{~h}$ & 13 to $26 \mathrm{~h}$ & 26 to $39 \mathrm{~h}$ & 39 to $52 \mathrm{~h}$ & 52 to $65 \mathrm{~h}$ \\
\hline T39 & $40^{\circ} \mathrm{C}$ & $39^{\circ} \mathrm{C}$ & $40^{\circ} \mathrm{C}$ & $39^{\circ} \mathrm{C}$ & $40^{\circ} \mathrm{C}$ \\
T40 & $41^{\circ} \mathrm{C}$ & $39^{\circ} \mathrm{C}$ & $41^{\circ} \mathrm{C}$ & $39^{\circ} \mathrm{C}$ & $41^{\circ} \mathrm{C}$ \\
T41 & $42^{\circ} \mathrm{C}$ & $39^{\circ} \mathrm{C}$ & $42^{\circ} \mathrm{C}$ & $39^{\circ} \mathrm{C}$ & $42^{\circ} \mathrm{C}$ \\
T42 & $43^{\circ} \mathrm{C}$ & $39^{\circ} \mathrm{C}$ & $43^{\circ} \mathrm{C}$ & $39^{\circ} \mathrm{C}$ & $43^{\circ} \mathrm{C}$ \\
T43 &
\end{tabular}

${ }^{1}$ Cells were exposed to $39^{\circ} \mathrm{C}$ continuously (T39) for the 65 -h incubation period, or to three 13 -h cycles at 40 (T40), 41 (T41), 42 (T42), or $43^{\circ} \mathrm{C}$ (T43), respectively, interspersed with two 13 -h cycles at $39^{\circ} \mathrm{C}$.

$13,000 \times g$ for $10 \mathrm{~min}$ and the supernatants were collected and kept on ice until analyzed by an automatic analyzer for clinical chemistry (Monarch 1500-Plus, International Laboratory, Lexington, IL). Analysis was carried out by the use of a commercial kit purchased from Diacron (d-ROMs, Grosseto, Italy). Data were expressed in Caratelli units: 1 Caratelli unit is equal to a hydrogen peroxide concentration of $0.08 \mathrm{mg} / \mathrm{dL}$ (Cesarone et al., 1999).

Analysis of Hsp72 mRNA Levels. Levels of Hsp72 mRNA were measured by real-time reverse transcription PCR. Total RNA was isolated from PBMC using Tri reagent (Sigma-Aldrich) following the procedure described by Bernabucci et al. (2004). The concentration of recovered RNA was measured at an optical density of $260 \mathrm{~nm}$. The quality of RNA was acceptable if the ratio of optical density at $260 \mathrm{~nm}$ to that at $280 \mathrm{~nm}$ was $>1.9$. Total RNA was reverse-transcribed with ImProm-II Reverse Transcription System (Promega, Madison, WI). One microgram of total RNA was reverse transcribed in a final volume of $20 \mu \mathrm{L}$ with $0.5 \mu \mathrm{g}$ of oligo dT and incubated for reverse transcription at $42^{\circ} \mathrm{C}$ for $1 \mathrm{~h}$. Then, reverse transcriptase was inactivated at $70^{\circ} \mathrm{C}$ for $15 \mathrm{~min}$. Aliquots of cDNA were subjected to real-time PCR, in which Quantitect SYBR Green PCR Master Mix (Qiagen s.p.a., Milan, Italy), and primers for Hsp72 and GAPDH were used. Primers were designed with Polyprimers software (Valentini, 2006) based on the sequences obtained from the GenBank Sequence Database and synthesized by MWG-Biotech (Ebersberg, Germany). The sequences of primers are as follows: bovine Hsp72 (Genbank Accession No. U02892) 5'-AACATGAAGAGCGCCGTGGAGG-3' (sense) and 5'-GTTACACACCTGCTCCAGCTCC-3' (antisense); bovine GAPDH (Genbank Accession No. BC102589) 5'-ACAGGGTGGTGGACCTCATGGT-3' (sense) and 5'-TGATGGTACACAAGGCAGGGCT-3' (antisense). The predicted sizes of PCR products are $169 \mathrm{bp}$ for Hsp72 and $213 \mathrm{bp}$ for GAPDH. The cDNA samples were amplified in a real-time fluorescence thermal cycler (LightCycler 3.5, Roche Applied Science, Penzberg, Germany) in capillary tubes. Amplification reactions were conducted for 45 cycles of heating to $95^{\circ} \mathrm{C}$ (denaturation, $10 \mathrm{~s}$ ), cooling to $61^{\circ} \mathrm{C}$ and $59^{\circ} \mathrm{C}$ for Hsp72 and GAPDH, respectively (annealing, $20 \mathrm{~s}$ ) and heating to $72^{\circ} \mathrm{C}$ (extension, $16 \mathrm{~s}$ ). The rate of all temperature changes was $20^{\circ} \mathrm{C} / \mathrm{s}$. Fluorescence was acquired during the extension of each cycle. After amplification, a melting curve was acquired by heating at $20^{\circ} \mathrm{C} / \mathrm{s}$ to $95^{\circ} \mathrm{C}$, cooling at $20^{\circ} \mathrm{C} / \mathrm{s}$ to $65^{\circ} \mathrm{C}$, and slowly heating at $0.1^{\circ} \mathrm{C} / \mathrm{s}$ to $95^{\circ} \mathrm{C}$ with fluorescence data collection at $0.1^{\circ} \mathrm{C}$ intervals, to verify the presence of a single amplicon. Before statistical analysis, data of mRNA for Hsp72 were normalized to the abundance of GAPDH. The abundance of GAPDH did not differ between breeds or treatments (data not shown).

\section{Statistical Analysis}

Data were reported as least squares means \pm standard errors of the mean (SEM). Data were analyzed using the GLM procedure of SAS (SAS Institute, 1995). The model included effects of breed (Br or Ho), treatments $(n=5)$, animal within breed, and error term. The effects were considered to be significant at a value of $P<0.05$. The Pearson correlation procedure of SAS (SAS Institute, 1995) was used to examine correlations between DNA synthesis and intracellular ROS or Hsp72 mRNA.

\section{RESULTS AND DISCUSSION}

\section{DNA Synthesis}

Increasing incubation temperature in both breeds decreased DNA synthesis of PBMC (Figure 1). Compared with values recorded under treatment $\mathrm{T} 39$, the extent of significant decreases ranged from $-21.9 \%$ ( $\mathrm{T} 41$ in $\mathrm{Br}$ cows) to $-97.7 \%$ (T43 in $\mathrm{Br}$ cows). In $\mathrm{Br}$, DNA synthesis began to decline in PBMC repeatedly exposed to $41^{\circ} \mathrm{C}$ (T41; $P<0.05$ ), whereas PBMC isolated from Ho cows were more resistant to heat exposure, and DNA synthesis did not begin to decline until cells were repeatedly exposed to $42^{\circ} \mathrm{C}$ (T42; $P<0.01$ ). Under T41 and T42, DNA synthesis in PBMC from Br cows was lower than 


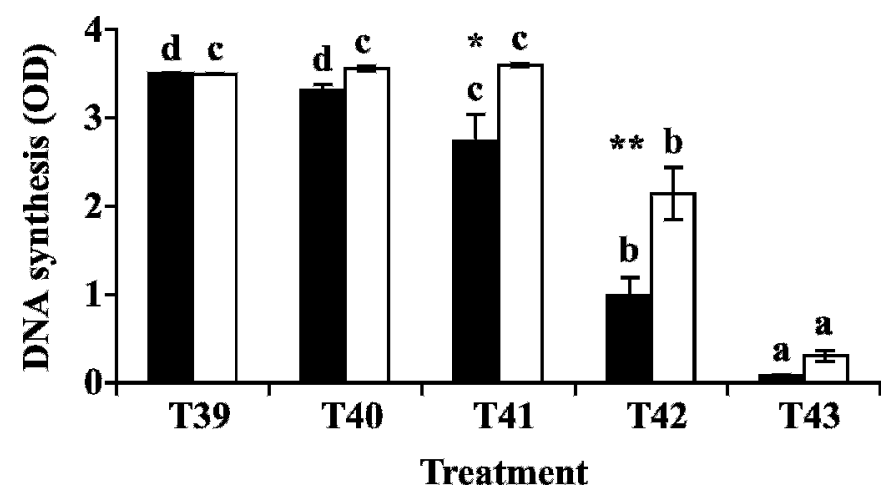

Figure 1. Synthesis of DNA (optical density, OD) in concanavalin A-stimulated peripheral blood mononuclear cells (PBMC) isolated from Brown Swiss (solid bars) and Holstein (open bars) cows. The PBMC isolated from the 10 cows were subjected to each of 5 treatments. Under treatment T39, PBMC were exposed to $39^{\circ} \mathrm{C}$ continuously; under T40, T41, T42, and T43, three 13 -h cycles at 40, 41, 42, or $43^{\circ} \mathrm{C}$ were interspersed with two 13 -h cycles at $39^{\circ} \mathrm{C}$. Data represent least squares means \pm SEM. ${ }^{a-d}$ Different letters indicate significant differences between treatments within breed $(P<0.0001)$. Asterisks indicate significant differences between breeds within treatments $(* P<0.001, * * P<0.0001)$.

that recorded in Ho $(P<0.001$ and $P<0.0001$, respectively).

Results reported herein demonstrated that incubation temperatures simulating hyperthermia impaired DNA synthesis in mitogen-stimulated PBMC. Additionally, the present study demonstrated that between the 2 breeds studied, the breed considered better adapted to hot climates $(\mathrm{Br})$ had lower cellular tolerance to heat. Studies on the effects of air temperatures above the upper critical temperature on immune cell functions in bovine provided contradictory results. Some authors reported an improvement (Soper et al., 1978); some described impairment (Elvinger et al., 1991; Kamwanja et al., 1994; Lacetera et al., 2005); and others indicated no effects (Lacetera et al., 2002) of heat exposure on lymphocyte functions. The large variety of experimental conditions (e.g., in vivo vs. in vitro, field vs. controlled environment, animals from different breeds or different ages, duration and intensity of heat exposure, lymphocyte function studied) likely explains the discrepancy among results. However, results of the present in vitro study and those derived from a previous in vivo study (Lacetera et al., 2005), indicate that prolonged exposure to severe heat stress is responsible for a decline of immune cells' reactivity, which may contribute to the higher occurrence of some infections during summer (Cook et al., 2002).

No comparative studies have been conducted to establish differences in lymphocyte tolerance to heat stress between $B$. taurus breeds. Previous studies focusing on tolerance to heat of bovine lymphocytes were

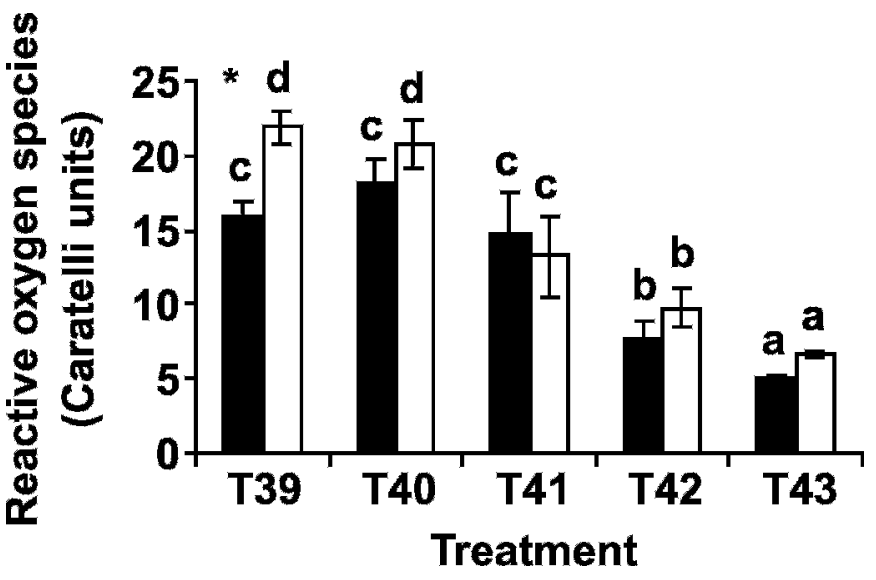

Figure 2. Intracellular content of reactive oxygen species (ROS) in concanavalin A-stimulated peripheral blood mononuclear cells (PBMC) isolated from Brown Swiss (solid bars) and Holstein (open bars) cows. The PBMC isolated from the 10 cows were subjected to each of 5 treatments. Under treatment T39, PBMC were exposed to $39^{\circ} \mathrm{C}$ continuously; under T40, T41, T42, and T43, three 13 -h cycles at $40,41,42$, or $43^{\circ} \mathrm{C}$ were interspersed with two 13 -h cycles at $39^{\circ} \mathrm{C}$. The ROS were determined on PBMC lysate by an automatic analyzer for clinical chemistry and by the use of a commercial kit; 1 Caratelli unit is equal to a hydrogen peroxide concentration of $0.08 \mathrm{mg} / \mathrm{dL}$. Data represent least squares means \pm SEM. ${ }^{a-d}$ Different letters indicate significant differences between treatments within breed $(P<0.0001)$. Asterisk indicates significant differences between breeds within treatments $(* P<0.005)$.

carried out comparing $B$. indicus and B. taurus subspecies. Genetic differences in thermotolerance have been shown for apoptosis response in lymphocytes, with Brahman and Senepol cattle being more resistant to heat shock than Angus and Holstein breeds (PaulaLopes et al., 2003). Furthermore, a series of studies recently reviewed by Hansen (2004) documented that cellular tolerance to heat is higher in $B$. indicus breeds when considering cell populations other than lymphocytes (e.g., endometrial cells, embryos). The mechanisms responsible for the higher heat tolerance of cells from $B$. indicus breeds have not been clarified. These studies indicated that breeds considered better adapted to hot climates (e.g., B. indicus) have higher tolerance to heat at the cellular level.

\section{Intracellular ROS}

Increasing incubation temperature significantly decreased intracellular ROS in PBMC isolated from both breeds (Figure 2). Significant decreases in ROS ranged from $-39.6 \%$ ( $\mathrm{T} 41$ in Ho cows) to $-69.7 \%$ (T43 in Ho cows) compared with T39. Intracellular ROS in Br cows began to decline in PBMC subjected to T42 (-52.1\%; $P$ $<0.001$ ), whereas in Ho cows, intracellular ROS started to decline when cells were subjected to T41 $(P<0.01)$. Only under T39 did values of intracellular ROS differ 
between the 2 breeds, with higher values in Ho cows $(P<0.005)$. A positive correlation was found between DNA synthesis and intracellular ROS for $\mathrm{Br}$ and $\mathrm{Ho}$ cows $(\mathrm{r}=0.85, P<0.0001)$.

The present study showed a decline of intracellular ROS in PBMC exposed to increased temperature, and a positive correlation between intracellular ROS and DNA synthesis. These results are consistent with studies in other species indicating that higher intracellular ROS is associated with greater cellular proliferation to mitogen (Hildeman, 2004). Furthermore, it is likely that our temperature-related reduction of proliferation was associated with reduction of cellular metabolic rate, which may be responsible for lower intracellular ROS production (Shigenaga and Ames, 1994). Several studies in humans, laboratory animals (Flanagan et al., 1998), and dairy cattle (Bernabucci et al., 2002) demonstrated that hyperthermia could be responsible for oxidative stress and subsequent cell damage by promoting free radical formation and increased lipid peroxidation. But, both direct and indirect evidence demonstrate that in bovine cells (embryonic), free radical production is not a crucial determinant of the effects of heat shock (Paula-Lopes et al., 2003). Malayer et al. (1992) reported that the addition of antioxidant agents to culture medium could prevent heat-induced killing of bovine lymphocytes even though the mechanism of such a protective effect was not clarified. Our results support the hypothesis that effects of heat on bovine cells should not be ascribed to increased ROS formation. However, further studies are needed to clarify whether heat shock can cause oxidative stress by altering cellular antioxidant protection systems (Flanagan et al., 1998).

\section{Hsp72 mRNA}

Increased Hsp mRNA was detected in T41 $(+53.2 \%$; $P<0.05)$ and T43 (+80.4\%; $P<0.0001)$ compared with T39 in PBMC from Br cows (Figure 3). No differences were found in PBMC from Ho cows among different treatments. Under T41, T42, and T43, mRNA for Hsp72 in $\mathrm{Br}$ cows was higher than in $\mathrm{Ho}(P<0.005, P<0.05$, and $P<0.0001$, respectively). Significant negative correlations were detected between DNA synthesis and Hsp72 mRNA ( $\mathrm{r}=-0.70, P<0.001)$.

Our results on Hsp72 mRNA levels are novel, and cannot be compared with previous findings. To our knowledge, measurement of Hsp mRNA levels in cells exposed to temperature regimens that mimic conditions of chronic hyperthermia alternated with normothermia (which characterize, respectively, daytime and nighttime periods during hot seasons) has not been conducted before. Previous studies performed in bovine or other species evaluated mRNA levels or synthesis of

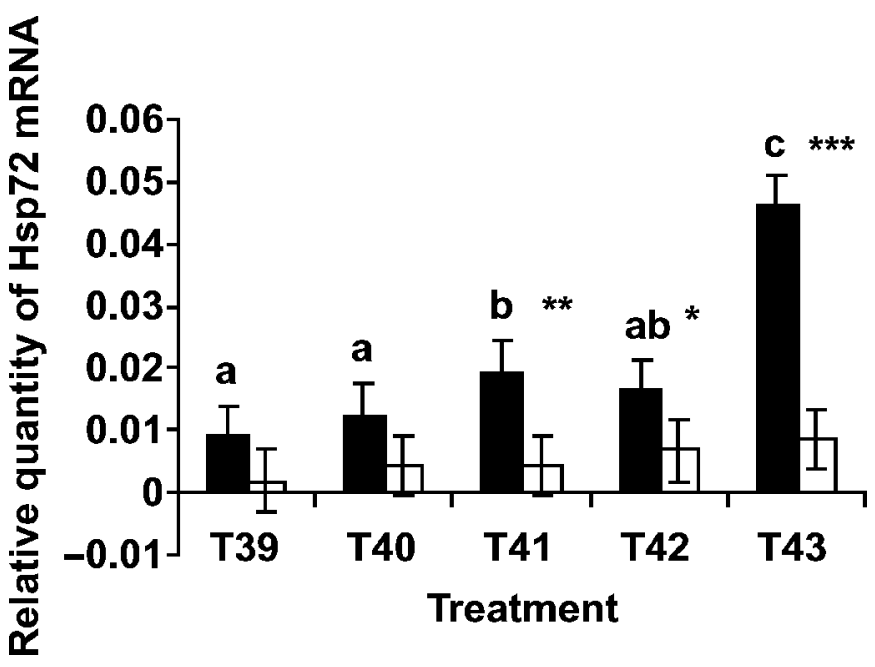

Figure 3. Levels of mRNA (expressed in arbitrary units relative to expression of GAPDH mRNA) for heat-shock protein 72 (Hsp72) in concanavalin A-stimulated peripheral blood mononuclear cells (PBMC) isolated from Brown Swiss (solid bars) and Holstein (open bars) cows. The PBMC isolated from the 10 cows were subjected to each of 5 treatments. Under treatment T39, PBMC were exposed to $39^{\circ} \mathrm{C}$ continuously; under T40, T41, T42, and T43, three 13 -h cycles at $40,41,42$, or $43^{\circ} \mathrm{C}$ were interspersed with two 13 -h cycles at $39^{\circ} \mathrm{C}$. Data represent least squares means \pm SEM. ${ }^{a-c}$ Different letters indicate significant differences between treatments within breed $(P$ $<0.0001$ ). Asterisks indicate significant differences between breeds within treatments $(* P<0.05, * * P<0.005$, $* * * P<0.0001)$.

Hsp following short-term exposure to heat-shock conditions. Kamwanja et al. (1994) found higher cellular resistance to elevated temperatures in lymphocytes from Brahman and Senepol cattle with respect to Angus cattle. They found a tendency for a lower amount of Hsp70 in the 2 thermotolerant breeds. Hansen (2004) speculated that the reduced Hsp70 expression in heatstressed Brahman and Senepol cattle might be indicative of reduced protein denaturation (one of the signals for Hsp70 synthesis). Accordingly, others indicated that activation of Hsp genes is primarily related to the defense against cell damage consequent to heat shock (Schiaffonati and Tiberio, 1997), or that Hsp70 expression is positively related with increase of cell injury score (Tokyol et al., 2005). Recently, Kristensen et al. (2004) suggested that increase of Hsp72 expression might function as a biological indicator for changes in the stress level. These observations may be of help to explain the lower amount of Hsp72 mRNA found in our study in PBMC from Ho, which presented the higher tolerance to heat.

On the other hand, Lindquist (1986) indicated that the heat-shock response is accompanied by a reduction in protein synthesis, favoring induction of the heatshock response over the ongoing gene program. Results of our study, and in particular the negative correlation 
found between mRNA for Hsp72 and DNA synthesis, are consistent with this hypothesis indicating that expression of the Hsp72 may be detrimental for the mitogen-driven proliferation gene program. Conversely, this interpretation of our findings conflicts with a series of previous studies indicating that elevated Hsp mRNA levels are associated with enhanced heat tolerance (Horowitz, 2002). In this case, utilization of cells isolated from species different from cows and different from PBMC, and adoption of different intensity and duration of exposure to heat shock likely explains the discrepancies. Finally, our results suggest that further research is needed to verify whether mechanisms different from Hsp may exist in bovine, which may confer thermotolerance to cells undergoing proliferation.

Finally, our study did not indicate whether the different steady-state mRNA levels of Hsp72 in the 2 breeds depended on transcriptional or posttranscriptional regulation of gene expression. However, previous studies conducted indicated that mRNA levels of Hsp72 in cells exposed to stressful stimuli may depend either on transcriptional (Schiaffonati and Tiberio, 1997) or on posttranscriptional regulation (Kaarniranta et al., 2000) of gene expression. Additionally, they demonstrated that among the different mechanisms through which translational regulation may occur (pre-mRNA splicing, mRNA transport, mRNA stability), posttranscriptional regulation of Hsp70 gene expression occurs mainly by mRNA stabilization.

\section{CONCLUSIONS}

The differential effects of heat on proliferative response of mitogen-stimulated PBMC from Brown Swiss and Holstein cows would suggest that body temperature increases under heat-stress conditions may not be associated with the same degree of alteration of immune cell efficiency in the 2 breeds. Generalization of this concept indicates that impairment of cell functions may start at a different level of body hyperthermia.

\section{ACKNOWLEDGMENTS}

This study was financially co-supported by MIUR (PRIN 03) and Università degli Studi della Tuscia. The authors gratefully acknowledge Giorgina Kuzminsky for valuable technical help. We are grateful to Michal Horowitz for valuable discussion and critical evaluation of the manuscript.

\section{REFERENCES}

Bernabucci, U., N. Lacetera, B. Ronchi, and A. Nardone. 2002. Markers of oxidative status in plasma and erythrocytes of transition dairy cows during hot season. J. Dairy Sci. 85:2173-2179.
Bernabucci, U., B. Ronchi, L. Basiricò, D. Pirazzi, F. Rueca, N. Lacetera, and A. Nardone. 2004. Abundance of mRNA of apolipoprotein B100, apolipoprotein E, and microsomal triglyceride transfer protein in liver from periparturient dairy cows. J. Dairy Sci. 87:2881-2888.

Cesarone, M. R., G. Belcaro, and M. Caratelli. 1999. A simple test to monitor oxidative stress. Int. Angiol. 18:127-130.

Cook, N. B., T. B. Bennett, K. M. Emery, and K. V. Nordlund. 2002. Monitoring nonlactating cow intramammary infection dynamics using DHI somatic cell count data. J. Dairy Sci. 85:1119-1126.

Correa-Calderon, A., D. Armstrong, D. Ray, S. DeNise, M. Enns, and C. Howison. 2004. Thermoregulatory responses of Holstein and Brown Swiss heat-stressed dairy cows to two different cooling systems. Int. J. Biometeorol. 48:142-148.

Elvinger, F., P. J. Hansen, and R. P. Natzke. 1991. Modulation of function of bovine polimorphonuclear leukocytes and lymphocytes by high temperature in vitro and in vivo. Am. J. Vet. Res. 52:1692-1698

Flanagan, S. W., P. L. Moseley, and G. R. Buettner. 1998. Increased flux of free radicals in cells subjected to hyperthermia: Detection by electron paramagnetic resonance spin trapping. FEBS Lett. 431:285-286.

Hansen, P. J. 2004. Physiological and cellular adaptations of Zebu cattle to thermal stress. Anim. Reprod. Sci. 82-83:349-360.

Hildeman, D. A. 2004. Regulation of T-cell apoptosis by reactive oxygen species. Free Radic. Biol. Med. 36:1496-1504.

Horowitz, M. 2002. From molecular and cellular to integrative heat defense during exposure to chronic heat. Comp. Biochem. Physiol. 131:475-483.

Johnson, H. D. 1965. Environmental temperature and lactation (with special reference to cattle). Int. J. Biometeorol. 9:103-116.

Johnson, H. D. 1987. Bioclimate effects on growth, reproduction and milk production. Pages 35-57 in Bioclimatology and the Adaptation of Livestock. H. D. Johnson, ed. Elsevier, Amsterdam, The Netherlands.

Kaarniranta, K., C. I. Holmberg, H. J. Helminen, J. E. Eriksson, L. Sistonen, and M. J. Lammi. 2000. Protein synthesis is required for stabilization of hsp70 mRNA upon exposure to both hydrostatic pressurization and elevated temperature. FEBS Lett. 475:283286.

Kamwanja, L. A., C. C. Chase, J. A. Gutierrez, V. Guerriero, T. A. Olson, A. C. Hammond, and P. J. Hansen. 1994. Responses of bovine lymphocytes to heat shock as modified by breed and antioxidant status. J. Anim. Sci. 72:438-444.

Kristensen, T. N., P. Løvendahl, P. Berg, and V. Loeschcke. 2004. Hsp72 is present in plasma from Holstein-Friesian dairy cattle, and the concentration level is repeatable across days and age classes. Cell Stress Chaperones 9:143-149.

Lacetera, N., U. Bernabucci, B. Ronchi, D. Scalia, and A. Nardone. 2002. Moderate summer heat stress does not modify immunological parameters of Holstein dairy cows. Int. J. Biometeorol. 46:33-37.

Lacetera, N., U. Bernabucci, D. Scalia, B. Ronchi, G. Kuzminsky, and A. Nardone. 2005. Lymphocyte functions in dairy cows in hot environment. Int. J. Biometeorol. 50:105-110.

Lindquist, S. 1986. The heat-shock response. Annu. Rev. Biochem. 55:1151-1191.

Malayer, J. R., J. W. Pollard, and P. J. Hansen. 1992. Modulation of thermal killing of bovine lymphocytes and preimplantation mouse embryos by alanine and taurine. Am. J. Vet. Res. 53:689-694.

Pahlavani, M. A., and M. D. Harris. 1998. Effect of in vitro generation of oxygen free radicals on $\mathrm{T}$ cell function in young and old rats. Free Radic. Biol. Med. 25:903-913.

Paula-Lopes, F. F., C. C. Chase Jr, Y. M. Al-Katanani, C. E. Krininger III, R. M. Rivera, S. Tekin, A. C. Majewski, O. M. Ocon, T. A. Olson, and P. J. Hansen. 2003. Genetic divergence in cellular resistance to heat shock in cattle: Differences between breeds developed in temperate versus hot climates in responses of preimplantation embryos, reproductive tract tissues and lymphocytes to increased culture temperatures. Reproduction 125:285-294.

SAS Institute. 1995. SAS User's Guide. 4th ed. Version 6. SAS Inst., Inc., Cary, NC. 
Schiaffonati, L., and L. Tiberio. 1997. Gene expression in liver after toxic injury: Analysis of heat shock response and oxidative stressinducible genes. Liver 17:183-191.

Shigenaga, M. K., and B. N. Ames. 1994. Oxidants and mitochondrial decay in aging. Pages 63-106 in Natural Antioxidants in Human Health and Disease. B. Frei, ed. Academic Press, San Diego, CA.

Soper, F., C. C. Muscoplat, and D. W. Johnson. 1978. In vitro stimulation of bovine peripheral blood lymphocytes: Analysis of variation of lymphocyte blastogenic response in normal dairy cattle. Am. J. Vet. Res. 39:1039-1042.
Tizard, I. 1992. Veterinary Immunology. An Introduction. I. Tizard, ed. W. B. Saunders Company, Philadelphia, PA.

Tokyol, C., G. Karaorman, and M. Bastung. 2005. Effects of acute and adaptive hypoxia and heat shock on heat shock protein expression in hepatic tissue. High Alt. Med. Biol. 6:247-255.

Valentini, A. 2006. www.unitus.it/sag.

Welch, W. J. 1992. Mammalian stress response: Cell physiology, structure/function of stress proteins, and implications for medicine and disease. Physiol. Rev. 72:1063-1081. 